\title{
Glycolytic and Gluconeogenic Enzyme Activities in the Hereditary Obese-Hyperglycemic Syndrome and in Acquired Obesity
}

\author{
I. Seidmai, A. A. Horland and G. W. Teebor \\ Department of Pathology, New York University Medical Center, New York, USA
}

\begin{abstract}
Summary. Activities of hepatic "regulatory" glycolytic and gluconeogenic enzymes were assayed in obese-hyperglycemic mice and were found to be elevated over those observed in lean littermates. Qualitatively similar results were obtained when goldthioglucose-obese mice were compared with untreated controls. It therefore appears that these alterations of enzyme activity are not unique to the obese-hyperglycemic syndrome but reflect metabolic disturbances related to obesity per se. The unexpected elevation in the activities of the gluconeogenic enzymes are discussed. Glycolytic enzyme activity assayed in heart and striated muscle revealed no differences between obese-hyperglycemic mice and their lean littermates.
\end{abstract}

Les activités enzymatiques de la glycolyse et de la gluconéogénèse dans le syndrome obésité-hyperglycémie héréditaire (mutation obob) et dans l'obésité acquise

Résumé. Les activités des enzymes hépatiques régulateurs de la glycolyse et de la gluconéogénèse ont été étudiées chez la souris obèse-hyperglycémique. Celles-ci furent trouvées plus élevées que chez les animaux nonobèse d'une même nichée. Des résultats qualitativement semblables ont été obtenus lorsqu'on compare la souris rendue obèse par l'aurothioglucose aux animaux témoins non-traités. Il semblerait done que ces altérations de l'activité enzymatique ne se produisent pas uniquement dans le cas de syndrome obèse-hyperglycémique, mais

The usual experimental model of human diabetes is the alloxan-treated rat. Alloxan destroys the beta cells of the pancreatic islets, resulting in loss of the animal's capacity to synthesize insulin. Hyperglycemia and weight loss follow. This model has been compared to the juvenile form of human diabetes. Alterations in the activities of certain hepatic glycolytic and gluconeogenic enzymes are a consistent finding in alloxan diabetes. The activities of the glycolytic enzymes glucokinase, phosphofructokinase and pyruvate kinase fall; their activity is restored to normal by insulin. Conversely, the activities of the four gluconeogenic enzymes pyruvate carboxylase, phosphoenolpyruvate carboxykinase, fructose-1,6-diphosphatase, and glucose-6-phosphatase rise, and return to normal following insulin administration. These insulin-responsive enzymes have been termed "regulatory" or "key" enzymes in their respective pathways (Weber et al., 1965). The other enzymes of the glycolytic-gluconeogenic pathway are bifunctional and do not respond to a significant degree to changes in plasma insulin concentration (Weber et al., 1965).

From these and other findings in alloxan diabetes it has been suggested that insulin is an inducer of the "regulatory" glycolytic enzymes and a suppressor of the "regulatory" gluconeogenic enzymes. reflètent plutôt des déséquilibres métaboliques de l'obésité per se. L'accroissement inattendu des activités des enzymes gluconéogénétiques est discuté. L'activité des enzymes glycolytiques étudiée dans les muscles cardiaque et strié n'a pas révélé de différences entre les souris obèse-hyperglycémiques et les animaux normaux d'une même nichée.

Aktivität der glykolytischen und gluconeogenetichen En. zyme beim hereditären obes-hyperglykämischen Snydrom (Mutation obob) und bei erworbener Fettsucht

Zusammenfassung. Im Vergleich zu Kontrolltieren wurden in Leberextrakten von obob-Mäusen erhöhte Aktivitäten der Schlüsselenzyme sowohl der Glykolyse als auch der Gluconeogenese gefunden. Mit Leberextrakten von nach Goldthioglucose-Injektion hyperphagisch und fettsüchtig gewordenen Mäusen wurden ähnliche Resultate erhalten. Es scheint deshalb, daß diese Veränderungen des Profils der Enzymaktivitäten nicht primärer Natur, sondern durch die Fettsucht induziert sind. In Herzund quergestreifter Muskulatur waren bezüglich der Aktivität der glykolytischen Enzymkette keine Unterschiede zwischen $o b o b$-Mäusen und deren normalgewichtigen Geschwistern festzustellen.

Key-words: Obese mice, obese-hyperglycemic syndrome, diabetes, liver, muscle, heart, glycolysis, gluconeogenesis, insulin, mutation obob, spontaneous diabetes.

Recently a model similar to human maturity onset diabetes has become available as a mutant of the $\mathrm{C57} /$ BL strain of laboratory mouse. These mice become obese by six weeks of age, and are characterized by body weights two to three times normal, hyperglycemia and hyperinsulinemia. They are relatively inactive and hyperphagic. The syndrome is inherited as an autosomal recessive (Mayer, 1966; Westman, 1968).

In view of the enzyme alterations found in alloxan diabetes it was of interest to determine the activities of these insulin-responsive enzymes in this contrasting experimental model.

The activities of these enzymes were also studied in mice made obese by goldthioglucose (Marshall et al., $1955)$ to determine whether the obesity resulting from hyperphagia alone would result in abnormalities of hepatic enzyme activities.

\section{Materials and Methods}

Obese male mice (C57BL/6J-ob, Bar Harbor) and male lean littermates were obtained at about 2 months of age. Male Swiss-Albino mice weighing $25 \mathrm{~g}$ were purchased locally. Both groups of mice were maintained on Wayne Lab Blox ad libitum. 
The Swiss-Albino mice were injected intraperitoneally with $1 \mathrm{mg} / \mathrm{g}$ goldthioglucose. They were permitted to attain a weight of at least $70 \mathrm{~g}$ before use in the experiments. Age-matched uninjected mice served as controls.

Table 1. Liver weight/body weight ratio $(\times 100)$ of obesehyperglycemic and goldthioglucose obese mice and their controls. The values are the mean of at least 15 measurements $\pm S . E . M$.

\begin{tabular}{ll}
\hline Obese-hyperglycemic & Lean littermates \\
$7.7 \pm 0.2$ & $4.7 \pm 0.2$ \\
Goldthioglucose treated & Untreated Swiss-Albino mice \\
$\mathbf{5 . 4} \pm 0.1$ & $\mathbf{6 . 3} \pm 0.1$ \\
\hline
\end{tabular}

Table 2. Activities of hepatic glycolytic, bifunctional and gluconeogenic enzymes of congenitally obese mice and lean littermates. The values represent the mean of between 7 and 10 mice \pm S.E.M. Asterisks indicate that the results are significant statistically to at least the $P<0.05$ level

\begin{tabular}{|c|c|c|}
\hline & Lean & Obese \\
\hline \multicolumn{3}{|l|}{ Glycolytic enzymes } \\
\hline Glucokinase* & $0.5+0.05$ & $1.8+0.06$ \\
\hline Phosphofructokinase* & $2.1 \pm 0.1$ & $3.3 \pm 0.01$ \\
\hline Pyruvate kinase* & $10.0 \pm 0.8$ & $29.2 \pm 1.9$ \\
\hline \multicolumn{3}{|l|}{ Bifunctional enzymes } \\
\hline Phosphoglycerate kinase & $78.2+3.6$ & $84.6+2.0$ \\
\hline Lactate dehydrogenase* & $88.6 \pm 7.2$ & $141.0 \pm 6.2$ \\
\hline \multicolumn{3}{|l|}{ Gluconeogenic enzymes } \\
\hline Fructose-1,6-diphosphatase* & $2.5 \pm 0.2$ & $5.3 \pm 0.3$ \\
\hline Glucose-6-phosphatase* & $3.3 \pm 0.2$ & $5.8 \pm 0.3$ \\
\hline
\end{tabular}

Table 3. Activities of hepatic glycolytic, bifunctional and gluconeogenic enzymes of goldthioglucose obese mice and untreated controls. The values represent the mean of between 7 and 10 mice \pm S.E.M. Asterisks indicate that the differences are significant statistically to at least the $P<0.05$ level

\begin{tabular}{lll}
\hline & Lean & Obese \\
\hline Glycolytic enzymes & & \\
Glucokinase* & $0.3 \pm 0.038$ & $0.8 \pm 0.006$ \\
Phosphofructokinase* & $1.9 \pm 0.08$ & $3.3 \pm 0.2$ \\
Pyruvate kinase* & $14.3 \pm 1.5$ & $23.3 \pm 1.4$ \\
Bifunctional enzymes & & \\
Phosphoglycerate kinase* & $64.0 \pm 1.1$ & $79.0 \pm 6.1$ \\
Lactate dehydrogenase* & $66.0 \pm 3.4$ & $\mathbf{9 5 . 0 \pm 4 . 1}$ \\
Gluconeogenic enzymes & & \\
Fructose-1,6-diphosphatase* & $3.6 \pm 0.3$ & $4.8 \pm 0.1$ \\
Glucose-6-phosphatase* & $5.2 \pm 0.13$ & $6.8 \pm 0.36$ \\
\hline
\end{tabular}

The mice were sacrificed by cervical dislocation between 9-10 AM. The tissues were rapidly removed, weighed, minced in the cold, and were homogenized in the cold in a motor-driven Teflon-glass PotterElvejhem apparatus. The homogenization medium varied with the enzyme that was being assayed. Glucokinase (Blumenthal et al., 1964), phosphofructokinase (Underwood and Newsholme, 1965), pyruvate kinase
(Krebs and Eggleston, 1965), lactate dehydrogenase (Shonk and Boxer, 1964), phosphoglycerate kinase (Shonk and Boxer, 1964), glucose-6-phosphatase (Swanson, 1955) and fructose-1,6-diphosphatase (Mc Gilvery, 1955) activities were assayed by the methods indicated in the references. Hepatic enzyme activities were expressed as umoles of product formed per minute per mg DNA. DNA was determined by the Burton modification of the diphenylamine reaction (Burton, 1956). Heart and striated muscle enzyme activities were expressed as $\mu$ moles of product per minute per $\mathrm{mg}$ protein. Protein was determined by the Lowry method (Lowry et al., 1951).

\section{Results}

The liver weight/body ratios of the congenitally and goldthioglucose induced obese mice are recorded in Table 1. Although the degree of weight gain is similar in both forms of obesity, the liver weight/body weight ratios differ markedly. In the obese-hyperglycemic mice, the ratio is increased over that of the lean littermate, while in the goldthioglucose-obese mice, the ratio is lower than in the untreated mice.

The activities of the glycolytic enzymes were significantly elevated in the livers of the congenitally obese mice, substantiating our earlier results (Seidman et al., 1967) (Table 2). Of the bifunctional enzymes, lactate dehydrogenase activity was moderately elevated, while phosphoglycerate kinase activity was similar in both groups. The activities of the two gluconeogenic enzymes were also elevated. Qualitatively similar results were obtained when the lean SwissAlbino mice were compared to those made obese by goldthioglucose injection (Table 3).

The activities of the "regulatory" glycolytic enzymes were assayed in heart and striated muscle of the congenitally obese mice and the results were compared with those obtained with their lean littermates. The results (Table 4 ) show that no significant differences were observed between the two groups of mice.

\section{Discussion}

Mayer has stated that the congenitally obese mouse is an example of "metabolic" obesity and that the goldthioglucose mouse was an example of "regulatory" obesity and that there was a fundamental difference between these two types (Mayer, 1966). He demonstrated, for example, that the congenitally obese mice continue to synthesize fat in significant quantities during starvation, while goldthioglucose mice do not (Zomzely and Mayer, 1959). Furthermore, responses to epinephrine and insulin were demonstrated to be different in these two groups (Leboeuf et al., 1961). Indeed the differences in the liver weight/body weight ratios of the two types of obese mice suggest a fundamental difference in the pathogenesis of the obesity. 
We have demonstrated that both types of obesity result in qualitatively similar increases in the acitvities of the hepatic "regulatory" glycolytic and gluconeogenic enzymes. Hyperphagia will result in an increased intake of carbohydrate. It has been shown that a diet high in carbohydrate content will cause an elevation in the activity of hepatic pyruvate kinase, one of the enzymes of glycolysis measured in this experiment (Krebs and Eggleston, 1965). It was presumed that this elevation was secondary to the elevated levels of plasma insulin evoked by high dietary carbohydrate. It is felt that a similar mechanism is probably operative in congenital and induced obesity, both of which require hyperphagia for their development (Mayer, 1966). fore do not reflect the hyperinsulemia of the congenitally obese mouse.

An unexpected finding in both groups of obese mice was the elevation of the activities of the gluconeogenic enzymes fructose-1,6-diphosphatase and glucose6-phosphatase. This result was surprising in light of the evidence which has been presented that insulin is a suppressor of these enzymes. Glucocorticoids are known to elevate the activities of these gluconeogenic enzymes (Weber et al., 11965). The adrenal cortices of the congenitally obese mice are hyperplastic and Carstensen et al have demonstrated an increased synthesis of corticoids in vitro by segments of adrenal glands prepared from these animals (Carstensen et al., 1961). It is possible that the corticoid effect overrides

Table 4. Activities of glycolytic enzymes in the heart and striated muscle of congenitally obese mice and lean littermates. The values represent the mean of 5-10 mice \pm S.E.M.M.

\begin{tabular}{|c|c|c|c|c|c|c|}
\hline \multirow[b]{2}{*}{ Heart } & \multicolumn{2}{|l|}{ Glucokinase } & \multicolumn{2}{|c|}{ Phosphofructokinase } & \multicolumn{2}{|c|}{ Pyruvate kinase } \\
\hline & $\overline{\text { Lean }}$ & Obese & Lean & Obese & Lean & Obese \\
\hline $\begin{array}{l}\text { Striated } \\
\text { Muscle }\end{array}$ & $\begin{array}{l}0.025 \pm 0.003 \\
0.020 \pm 0.002\end{array}$ & $\begin{array}{l}0.031 \pm 0.005 \\
0.021 \pm 0.002\end{array}$ & $\begin{array}{l}0.295 \pm 0.02 \\
0.895 \pm 0.054\end{array}$ & $\begin{array}{l}0.298 \pm 0.03 \\
0.865 \pm 0.077\end{array}$ & $\begin{array}{c}0.740 \pm 0.031 \\
0.783 \pm 0.031\end{array}$ & $\begin{array}{l}3.23 \pm 0.24 \\
3.21 \pm 0.29\end{array}$ \\
\hline
\end{tabular}

We therefore conclude that the elevations of the enzyme activities reported above is a function of obesity per se and is not a finding unique to the obesehyperglycemic syndrome. With respect to some of the differences reported elsewhere between these two types of obese mice, the degree of obesity of the goldthioglucose mice was not of the same magnitude as that of the congenitally obese mice with respect to the controls. In those experiments, the mice treated with goldthioglucose weighed from 50 to $55 \mathrm{~g}$, with controls

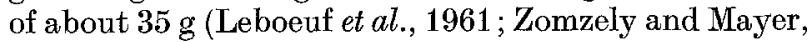
1959). Congenitally obese mice weighed $60 \mathrm{~g}$ or over, with controls of only $25 \mathrm{~g}$. The data presented in this report were obtained from goldthioglucose mice weighing between 70 and $80 \mathrm{~g}$. At this degree of obesity, goldthioglucose mice showed enzyme activities qualitatively similar to the congenitally obese mice. It may be that similarities in other physiologic parameters between the two groups of obese mice may become manifest if a comparable degree of obesity were obtained in the goldthioglucose mice.

The activities of the glycolytic enzymes assayed in heart and striated muscle were comparable in the congenitally obese mice and their lean littermates. Thus the relative inactivity of the obese mice cannot be explained by an abnormality of the glycolytic pathway. The "regulatory" glycolytic enzymes consist of isozymes which vary in their distribution in different tissues (Katzen and Schimke, 1965; Tanaka et al., 1965). The activities of some of the isozymes vary with the physiologic state of the host while others are nonresponsive. The isozymes of the regulatory enzymes present in muscle are of the latter variety and there- that of insulin and that increased gluconeogenesis is responsible, at least in part, for the hyperglycemia which characterizes this syndrome.

These experiments provide evidence that obesity, whether congenital or induced, leads to an altered metabolic state in which normal physiologic responses, such as the reciprocal behavior of the gluconeogenic and glycolytic pathways, are disturbed. Other normal responses may be altered in obesity and indeed there is evidence that the normal metabolic responses to starvation are modified or absent in the congenitally obese mouse (Fried, 1967; Seidman et al., 1969).

Acknowledgements. This work was supported by a grant from The United States Public Health Service (AM13046-01). The authors wish to acknowledge the excellent technical assistance of Miss Susan Schechter. Dr. P. Pearlman of the Schering Corp. kindly provided the goldthioglucose.

\section{References}

Blumenthal, M.D., Abraham, S., Chaikoff, I.L.: Dietary control of liver glucokinase activity in the normal rat. Arch. Biochem. 104, 215-224 (1964).

Burton, K.: A study of the conditions and mechanism of the diphenylamine reaction for the colorimetric estimation of deoxyribonucleic acid. Biochem. J. 62, 315323 (1956).

Carstensen, H., Hellman, B., Larsson, S.: Biosynthesis of steroids in the adrenals of normal and obese-hyperglycemic mice. Acta Soc. Med. upsalien. 66, 139-151 (1961).

Fried, G.H.: Pyruvic kinase activity in livers of hereditarily obese and thin mice. Fed. Proc. 26, 623 (1967).

Katzen, H.M., Schimke, R.T.: Multiple forms of hexokinase in the rat: Tissue distribution, age dependency, 
and properties. Proc. nat. Acad. Sci. 54, 1218-1225 (1965).

Krebs, H. A., Eggleston, L. V. : The role of pyruvate kinase in the regulation of gluconeogenesis. Biochem. J. 94, $3 \mathrm{c}-4 \mathrm{c}(1965)$.

Leboeuf, B., Lochaya, S., Leboeuf, N., Wood, F.C., Jr., Mayer, J., Cahill, G.F., Jr.: Glucose metabolism and mobilization of fatty acids by adipose tissue from obese mice. Amer. J. Physiol. 201, 19-22 (1961).

Lowry, O.H., Rosebrough, N.J., Farr, A.L., Randall, R.J.: Protein measurement with the Folin phenol rea. gent. J. biol. Chem. 193, 265-275 (1951).

Marshall, N.B., Barrnett, R.G., Mayer, J.: Hypothalmic lesions in goldthioglucose injected mice. Proc, Soc. exp. Biol. 90, 240-244 (1955).

Mayer, J.: Some aspects of the problem of regulation of food intake and obesity. New Engl. J. Med. 274, 662$673(1966)$.

McGilvery, R.W.: Fructose-1,6-diphosphatase from liver. In: Methods in Enzymology II, p. 543. (Eds. S.P. Colowick and N.O. Kaplan.) New York: Academic Press Inc. 1955.

Seidman, I., Horland, A.A., Teebor, G.W.: Hepatic glycolytic and gluconeogenic enzymes of the obesehyperglycemic mouse. Biochim. biophys. Acta 146, $600-603$ (1967)

- - - Unpublished observations (1969).

Shonk, C.E., Boxer, G.E.: Enzyme patterns in human tissues. I. Methods for the determination of glycolytic enzymes. Cancer Res. 24, 709-721 (1964).

Swanson, M.A.: Glucose-6-phosphatase from liver. In: Methods in Enzymology II, p. 541. (Eds. S. P. Colowick and N.O. Kaplan.) New York: Academic Press Inc. 1955.

Tanaka, T., Harano, Y., Morimura, H., Mori, R.: Evidence for the presence of two types of pyruvate kinase in rat liver. Biochem. biophys. Res. Comm. 21, 55-60 (1965).

Underwood, A.H., Newsholme, E.A.: Properties of phosphofructokinase from rat liver and their relation to the control of glycolysis and gluconeogenesis. Biochem. J. 95, 868-875 (1965)

Weber, G., Singhai, R.I., Stamm, N.B., Srivastaba, S.K. : Hormonal induction and suppression of liver enzyme biosynthesis. Fed. Proc. 24, $745-754$ (1965).

Westman, S.: Development of the obese-hyperglycaemic syndrome in mice. Diabetologia 4, 141 - 149 (1968).

Zomzely, C., Mayer, J.: X. Endogenous dilution of administered labeled acetate during lipogenesis and cholesterogenesis in two types of obese mice. Amer. J. Physiol. 196, 956-960 (1959).

\section{J. Seidman, M.D.}

Department of Pathology

New York University

Medical Center.

New York, N.Y., USA 